\section{Curriculum Development and Training on Flowers and Ornamental Plant Production Practices in Rural Senegal with Winrock International and the USAID Farmer-to-farmer Program}

\author{
John L. Griffis, Jr. ${ }^{1}$
}

ADDITIONAL INDEX WORDs. bedding plants, horticultural education, IPM, shade trees, volunteer

SUMMARY. In most highly developed countries, landscaping and ornamental plants are routine components of the urban environment. However, in many Third World countries, this is not the situation outside of the larger cities. Landscaping and ornamentals are associated with hotels, public parks, offices, government buildings, and wealth; they are not significant commodities in rural settings. However, as urban areas in these countries - such as Senegal-expand and modernize, there is an increased demand for ornamental plants. Senegal's urban population has almost doubled during the past five decades, increasing from $23 \%$ in 1960 to $43 \%$ in 2013 . New jobs and sources of income are available for individuals who are properly trained in ornamental plant production and maintenance. Senegal has several rural training centers where some courses in agronomy and vegetable production are taught, but ornamental plant production is not included in the curriculum. This U.S. Agency for International Development (USAID) Farmer-to-Farmer project was conducted at one of those rural training centers at Djilor to introduce ornamental horticulture into the curriculum and to make students aware of ornamental plant production practices and the opportunities available to them if they become involved in a horticulture business.

$\mathrm{T}$ The Farmer-to-Farmer program was initially authorized by Congress in the 1985 Farm Bill and was funded through Title $\mathrm{V}$ of Public Law 480. The program was later designated as the "John Ogonowski and Doug Bereuter Farmer-to-Farmer Program" in honor of one of the American Airlines pilots killed 11 Sept. 2001 and of former Congressman Bereuter, who initially sponsored the program. John Ogonowski was not only a pilot, but also a farmer who worked extensively training immigrants from Cambodia

Received for publication 8 Apr. 2019. Accepted for publication 10 June 2019.

Published online 17 September 2019

${ }^{1}$ Department of Ecology and Environmental Studies, Florida Gulf Coast University, 10501 FGCU Boulevard S., Ft. Myers, FL 33965

This paper is a part of a workshop titled "Urban Horticulture: From Local Initiatives to Global Success Stories" that was presented 3 Aug. 2018 during the American Society for Horticultural Science annual conference in Washington, DC.

J.L.G. is the corresponding author. E-mail: jgriffis@ fgcu.edu.

This is an open access article distributed under the $\mathrm{CC}$ BY-NC-ND license (https://creativecommons.org/ licenses/by-nc-nd/4.0/).

https://doi.org/10.21273/HORTTECH04380-19 as a farmer-mentor (U.S. Agency for International Development, 2019). The program was initiated to assist developing countries, middle-income countries, emerging markets, subSaharan African countries, and Caribbean Basin countries in increasing farm production and incomes. The Farmer-to-Farmer Program promotes sustainable economic growth, food security, and agricultural development worldwide. Volunteer technical assistance from U.S. farmers, agribusinesses, cooperatives, and universities helps developing countries improve productivity, access new markets, build local capacity, combat climate change, and conserve environmental and natural resources (U.S. Agency for International Development, 2019). This people-to-people exchange also promotes international goodwill, understanding of U.S. foreign assistance programs, and private involvement in development activities.
Although the program is administered by USAID, the agency does not have enough humanpower to operate it directly, so several organizations bid to conduct Farmer-to-Farmer operations in the various countries selected by USAID. The program mirrors the time frame of the Farm Bill that funds it, so contracts between these various agencies and USAID are for 5 years. Winrock International (Little Rock, AR) was the contractor designated to operate the program in Senegal during the 2013-18 funding cycle when I conducted my training program. Winrock International currently uses recruiters in the United States to find volunteers for the program, and the agency also posts volunteer opportunities on their website, www.winrock. org. On the website, each project is described briefly and anyone interested in volunteering for a project is invited to contact one of the recruiters to discuss the opportunity further. If the volunteer appears to be qualified for the project, the recruiter will usually share a more complex scope of work (SOW) with the prospective volunteer. That is what occurred with this project. The SOW executive summary stated that the Vocational Training Center (CFP) at Djilor had requested the support of a Farmer-to-Farmer volunteer for a 17-d volunteer assignment (including travel) to Djilor Saloum, Senegal. In Senegal, warm temperatures can be expected all year. Senegal registers more than 300 sunny days per year and there are two seasons: the dry season (December-April) and the rainy season (May-November). During the dry season, the average daily high is $85^{\circ} \mathrm{F}$ and the average low is $70^{\circ} \mathrm{F}$. During the rainy season, the average daily high is $82^{\circ} \mathrm{F}$ and the average low temperature is $78^{\circ} \mathrm{F}$ (Winrock International, unpublished data).

The production of ornamental plants and flowers could become an important sector of horticulture in Senegal, although there is very limited local knowledge. This sector has seen an important renewal of interest in the population (green spaces in urban houses), the municipalities (green spaces in main public squares

\begin{tabular}{llll}
\hline $\begin{array}{l}\text { Units } \\
\text { To convert U.S. to SI, } \\
\text { multiply by }\end{array}$ & U.S. unit & SI unit & $\begin{array}{l}\text { To convert SI to U.S., } \\
\text { multiply by }\end{array}$ \\
\hline$\left({ }^{\circ} \mathrm{F}-32\right) \div 1.8$ & ${ }^{\circ} \mathrm{F}$ & ${ }^{\circ} \mathrm{C}$ & $\left({ }^{\circ} \mathrm{C} \times 1.8\right)+32$
\end{tabular}


and along urban streets), and in businesses (green spaces around hotels and office buildings). With almost half of its population living in urban areas, Senegal is ahead of sub-Saharan Africa's average urbanization rate of $40 \%$. Senegal's urban population has almost doubled during the past five decades, increasing from $23 \%$ in 1960 to $43 \%$ in 2013 , and is projected to reach $60 \%$ by 2030 (Rouhana and Ranarifidy, 2016).

This posted opportunity was described as a training-of-trainers assignment during which the volunteer would train CFP trainers on flower and ornamental plant production practices for replication to their trainees. In addition, the volunteer would work with the training center to formalize a syllabus and curricula for use in future training on this important topic. It is important to keep in mind that the volunteer also needed substantial time to prepare for the assignment. I have been teaching various ornamental horticulture production classes for more than 20 years, I have had a lot of experience designing horticulture curricula, and I have already completed several Farmer-to-Farmer projects for Winrock International, so we were familiar with each other. I was pleased to accept the assignment when it was offered. Successful completion of the project depended on careful preparation of materials and ordering of supplies, as well as planning for both classes and meetings with trainers. Classes and training sessions were conducted in English and a translator was present to translate English lectures into the local language, Wolof, as well as into French if needed. Materials left in Senegal could be translated locally.

\section{Materials and methods}

Initial preparation for this project included an Internet search to determine which ornamental plants might already be used in Senegal. Looking at photos of hotels and office buildings in Dakar was somewhat helpful, but there were no links to any businesses specifically selling containerized ornamental plants. Some ornamental plants visible in photos of Dakar included bougainvillea (Bougainvillea glabra), crown-ofthorns (Euphorbia milii), bird-ofparadise (Strelitzia reginae), oleander
(Nerium oleander), coconut (Cocos nucifera), and other assorted palm (Arecaceae) trees (Figs. 1 and 2). The Plant Resources of Tropical Africa (PROTA) project on African ornamentals was marginally helpful (PROTA Foundation, 2011) with regard to just a few plants with potential, and a recent popular online article about amateur florists in Senegal (Ning, 2017) gave some direction to business possibilities that needed to be discussed. I suggested a range of materials and supplies required for this project that would be left in Djilor, including horticulture textbooks, a binder filled with "how to grow bedding plants from seed" informational inserts, bedding plant seeds, a handheld $\mathrm{pH}$ meter and a handheld electrical conductivity (EC) meter, integrated pest management (IPM) videos and IPM general guides, numerous presentations in PowerPoint (Microsoft, Redmond, WA), and copies of various horticulture syllabi and curricula examples from various colleges that offer horticulture. I also brought a positive attitude to the project, which is very important. A volunteer expert needs to be flexible with regard to both schedule and presentation situations. Volunteer horticulture experts need to have many of the same traits as those desired in paid international horticulture consultants such as cultural sensitivity, openness, patience, innovativeness, and the ability of transfer knowledge and evaluate performance (Ebel and Shock, 2017). The original schedule for the project is summarized in Table 1.

The schedule turned out to be very workable. After the day in the Winrock offices, we were able to visit several roadside ornamental plant production plots scattered around the edges of Dakar. We traveled several hours to Djilor as planned, stopping at Foundiougne, where our hotel was located (there are several hotels in this town and they all have some ornamental plantings). We met with the director of the CFP and some of the faculty. We discussed the training sessions and room requirements for the next week. We determined there was only one known local producer of ornamental plants, so we visited him to see what he was producing-mostly bougainvillea and hibiscus (Hibiscus rosa- sinensis) from cuttings. We discovered the CFP had a community open house scheduled for the next day (Saturday), so we planned to attend. The open house was very well attended by the local citizenry, and students in the fashion design, tailoring, and culinary arts tracks were able to put their talents on display. However, it turned out that the planned classroom methodology needed modifications. The CFP director initially suggested I train both the current students and the training center faculty simultaneously, but after the weekend open house at the training center, he decided to invite any interested nearby farmers to attend the training. The original training concept was to conduct lectures and laboratories as examples, so that the faculty could see how materials can be used in a classroom setting. As one might expect, the decision to include local farmers resulted in a decision to

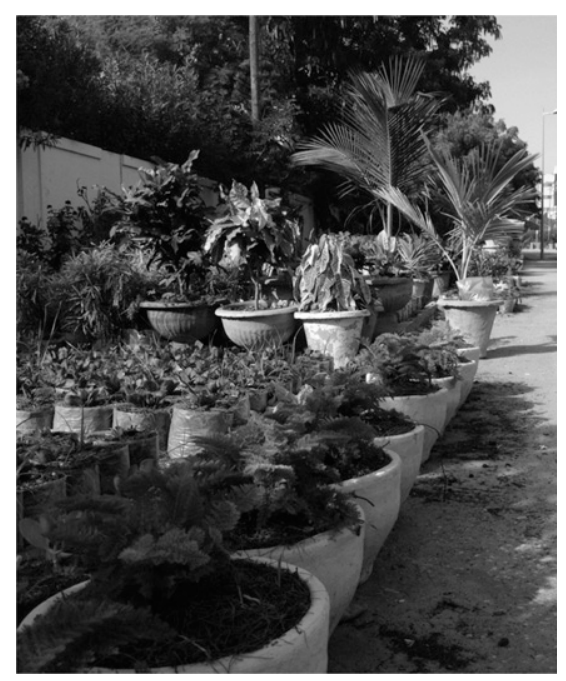

Fig. 1. Potted ornamental plants for sale along a street in Dakar, Senegal.

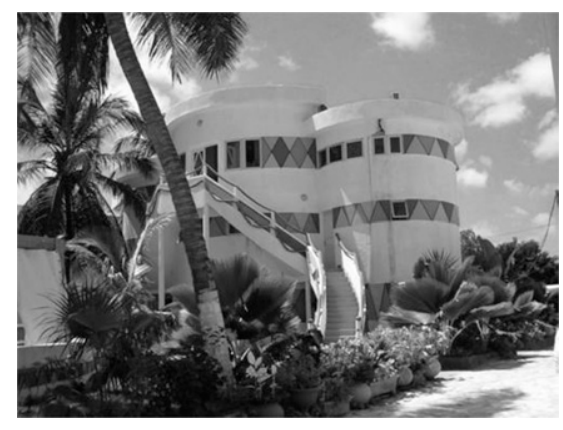

Fig. 2. Ornamental plantings at a hotel in Dakar, Senegal. 
Table 1. Proposed project schedule with deliverables for the curriculum development and training on flowers and ornamental plant production practices for the rural Senegal volunteer project.

Tasks to be performed:

1) Before leaving the United States:

- Conduct online research and read reports on Senegalese flowers and ornamental plant production.

- Find out possible vegetal material able to be grown in Senegal.

- Develop training materials that can easily be assimilated and disseminated. Visual aids, PowerPoint (Microsoft, Redmond, WA), videos, and so on, are highly recommended because of the low skill average and education level of the host.

- Winrock International (Little Rock, AR)/USAID (Washington, DC) requires that the volunteer submit a draft syllabus for this assignment for review and translation before implementation.

2) In-country:

- Train Vocational Training Center (CFP) trainers on flowers and ornamental plant production.

- Assist CFP trainers in writing syllabus/curriculum on flowers and ornamental plant production.

Activity

Location

Estimated time (d)

Travel to Dakar

Brief Winrock International staff; acquire information on the Dakar

1

host

Visit flower and ornamental plant production plots in Dakar

Travel to Djilor

Visit flower and ornamental plant production plots in Djilor; write and complete a new syllabus/curriculum and associated training materials on flower and ornamental plant production

Rest

Train CFP trainers on flowers and ornamental plant production

Travel to Dakar

Debrief with Winrock International trainers and submit final reports

Return to the United States

Total time (d)

1

Dakar

Djilor

Djilor

4

Foundiougne 1

Djilor

5

Dakar

1

Dakar

1

1

17

End of Assignment Report and other deliverables required:

1. End-of-assignment report (format provided by Winrock International)

2. Syllabus/curriculum and training materials related to flower and ornamental plant production

3. Pesticide evaluation report and safe use action plan that addresses pesticide use and the annex (U.S. Agency for International Development preformat provided)

alter the planned program a bit because the audience changed. The main difference was in the delivery of the lectures themselves, during which it was important to draw the farmers into the presentations by asking them frequently to comment on some topic with which they might be familiar. For example, I might ask whether any of the farmers had ever grown a particular plant, such as bougainvillea, that I saw growing in the area. Farmers who replied positively would be asked to tell the group about any experiences they had with the plant (the same technique could be applied to dealing with familiar insect pests). It was also important to be sure everyone understood any new concepts that were introduced, rather than assume a topic had already been covered in a prior class. The classroom phase was divided into 1 ) introduction to and uses of various ornamental plants, 2) introduction to bedding plants and seed propagation, 3 ) introduction to cutting propagation using local ornamental plants from the hotels, 4) water quality and fertilization practices, and 5) IPM. Training materials included PowerPoint presentations, videos, handouts, plastic bags and paper towels for seed germination, seeds, hand lenses, handheld $\mathrm{pH}$ and $\mathrm{EC}$ meters, local plant materials, and various other local items as needed. Completion certificates were prepared for all who attended most or all of the classes.

\section{Results and discussion}

A successful project included submission of the deliverables listed in Table 1. A final report was prepared for Winrock International, which provided detailed answers to a number of questions, some of which are summarized in the following text.

"What activities and assistance were part of your assignment? Who was involved? What topics were addressed? (Details regarding any materials developed, the number of people trained, the organizations that participated in your programs or with which you met, and so on, are all very important)." I was requested to introduce to trainees the concepts of ornamental horticulture (both potted plants for both home and landscape as well as cut flowers) as a possible smallbusiness enterprise. The idea was to train students and instructors in this area of horticulture, which appears to be new to most of Senegal outside of Dakar. The 4-d short course in ornamental horticulture was designed to help the students understand the 
possible roles ornamental plants can play in society and to help trainees understand how to propagate many ornamental plants, how to manage $\mathrm{pH}$ and total dissolved salts (TDS) or EC in irrigation water (important for any horticulture crop), and how to manage pests and diseases that often cause problems for growers. This included both lecture materials and some hands-on exercises with flower seeds, cuttings, tests of $\mathrm{pH}$ and $\mathrm{EC}$ of water from different sources, and diagnosing pest problems and learning how to resolve them without using pesticides when possible.

The day 1 lectures initially centered on ornamental plants and the functions they serve. It came as a surprise to trainees that shade trees (very important in areas like Djilor) are ornamentals. Other ornamental plants can also serve as living fences or as barriers and borders to control animals and limit access to areas. Trainees had not considered these ideas previously. The training presentation then offered examples of uses for ornamental plants, including those mentioned earlier, as well as ornamental garden plantings, potted plants, and bouquets of cut flowers. The first day concluded with an exercise in germinating flowers seeds [assorted zinnia (Zinnia elegans) cultivars] in plastic bags.

Day 2 training continued the introduction to various ornamental plants that could be propagated by seed. Many plants were discussed that should be appropriate for growing in Djilor or other areas of Senegal. Concepts of growing plants in pots for sale were discussed, including items such as soil type, fertilizer, and even selling potted plants at local markets. In the second session of day 2 , local plants with ornamental potential were examined in some detail, including flowering plants, shrubs, and small trees such as scarlet cordia (Cordia sebestena), physic nut (Jatropha curcas), variegated devil's backbone (Pedilanthus tithymaloidas 'Variegatus'), hibiscus, and bougainvillea, which grow around hotels and homes in the local area and in Dakar. Some of these plants could be propagated by seed, but it would be better to propagate some of them from cuttings to produce marketable plants much more quickly. An in-depth presentation [including shorts videos from youtube. com (YouTube, San Bruno, CA)] on cutting propagation of these plants was provided, and a demonstration of cutting propagation of bougainvillea completed the session.

The day 3 session started with a discussion of $\mathrm{pH}$ and $\mathrm{EC} / \mathrm{TDS}$ for horticulture, not just for ornamentals. A demonstration of how to use handheld, inexpensive, battery-powered $\mathrm{pH}$ meters and EC/TDS meters was provided. The program then discussed fertilization practices. From there, the program moved into IPM concepts. Examples of cultural practices that can help growers better manage animal pests, insect pests, weeds, and diseases were provided. Trainees were given information concerning best management practices. Recognizing insect life cycles is an important part of scouting crops, so several short videos were presented that show how pest insects develop from eggs or immature stages to adults. Well-known insect pests present in the local area were discussed in some detail, including mealy bugs (Pseudococcidae), aphids (Aphidoidae), spider mites (Tetranychidae), and leaf miners (Lepidoptera and Diptera). Examples of these pests feeding on local plants were brought into the classroom for close examination. Hand lenses provided by a previous volunteer at the Djilor Training Center proved to be very useful for trainees to observe the pests closely. We examined the seeds planted on day 1 , and, by then, most trainees had germinated seeds ready for transplant.

Training day 4 started with an examination of more insect pests on horticultural plants, such as eggplant (Solanum melongena), tomato (Solanum lycopersicum), sweetpotato [Ipomoea batatas (it is also considered an ornamental)], jujube (Ziziphus jujuba), and the local small flowering milkweed tree (Calotropis procera). Skill in diagnosing pest and disease problems is essential to proper pest management. Discussion included what to look for and how to tell whether problems were caused by pests, diseases, or environmental factors. Possible control methods (other than chemicals) were discussed, and additional videos were presented concerning mechanical control of aphids and other pests on leaves. Control of ants (Formicidae) is often a critical factor in pest management, and some possible methods were presented. The session ended with trainees removing germinated ornamental seedlings (zinnia) from day 1 and planting some of them up in small plastic bags filled with soil. Participants were encouraged to take the rest of the seedlings home (each student started with $\approx 25$ seeds) and plant them in other pots or directly in the garden. Afterward, I presented the director with five books concerning plant propagation from seeds and other methods, two $\mathrm{pH}$ test kits, batterypowered $\mathrm{pH}$ and $\mathrm{EC}$ meters, a large number of commercial packets of seeds of various ornamentals, and a manual/binder filled with information specifically about growing and managing these ornamental seedpropagated crops.

Several other detailed comments were required for the final report. Perhaps one of the more important questions asked: "What future impacts do you anticipate as a result of your assignment? (Please explain and list ways in which you think the results of your assignment can be measured 6 months from now.)" First, trainees are much more aware of ornamental horticulture and the new economic opportunities growing ornamentals might offer them. They should now understand that shade trees are ornamentals (and there is clearly a market for shade in the Djilor area). They should understand that ornamentals, such as flowering potted plants, could be items to sell in the market or send to Dakar, where some innovators are already marketing ornamentals to the city residents along some of the roadways. It is possible that some of the trainees might try out an ornamental horticulture business.

Second, some of the IPM concepts and practices that were discussed may be attempted by the students on various crops (ornamental or otherwise). They were unaware that ants could move other pests such as mealybugs and aphids from crop to crop or that ants will protect the pests from other insects that would feed on the pests. Controlling ants and other common horticultural insects may reduce the occurrence of a number of insect pests that can cause significant damage to ornamental plants, vegetables, and fruit. Because repelling ants and washing off pests are low-cost 
solutions (compared with chemical controls), some of the trainees that are already growing crops may try the techniques discussed.

Third, trainees should be more aware of the effects that $\mathrm{EC}$ and $\mathrm{pH}$ (water and soil) can have on crops, and they have been provided with a few simple ways to address the situations if crops (ornamental or otherwise) are not performing well because of these issues. Most trainees were aware of the concepts of $\mathrm{pH}$, but not exactly how to apply the ideas to the field and to plant production. Hopefully, they now have a better idea about it. Since completing this project in Senegal, I have been in frequent contact with one of the center instructors and I have provided additional information to assist him in teaching horticulture to trainees at Djilor CFP.

\section{Literature cited}

Ebel, R. and C.C. Shock. 2017. How to succeed as an international horticultural consultant. HortScience 52:1151-1155.

Ning, G. 2017. Amateur florists thrive in Senegal's plant industry. 15 May 2018. <https://news.cgtn.com/news/ 3d6b544d7a497a4d/share_p.html>.
PROTA Foundation. 2011. African ornamentals, proposals and examples. PROTA Foundation, Wageningen, The Netherlands.

Rouhana, S. and D. Ranarifidy. 2016. Cities for an emerging Senegal. Africa Can End Poverty, World Bank . . . Blogs. 15 June 2018. <http://blogs.worldbank. org/africacan/cities-for-an-emergingsenegal>.

U.S. Agency for International Development. 2019. Farmer to farmer, the USAID John Ogonowski and Doug Bereuter farmer-to-farmer program. 4 Apr. 2018. <http://farmer-to-farmer. org/about $>$. 